\title{
A method for choosing the optimal quantity of short-circuit indicating devices to enhance power supply reliability
}

\author{
$D$. Köppen ${ }^{1, *}, O . V$. Vladimirov ${ }^{2}, T . A$. Musaev $^{3}$, and $O . V$. Fedorov $^{4}$ \\ ${ }^{1}$ Research and development department, "Lenze", Extertal, Germany \\ ${ }^{2}$ Kazan State Power Engineering University, Kazan, Russia \\ ${ }^{3}$ JSC "Grid company", Kazan, Russia \\ ${ }^{4}$ Nizhny Novgorod State Technical University n.a. R.E. Alekseev, Nizhny Novgorod, Russia
}

\begin{abstract}
This article considers a method for solving the problem of choosing the optimal quantity of short-circuit indicating devices for providing a required reliability of the $6(10) \mathrm{kV}$ distribution power grid. Compatibility of the equipment powered was taken into account. An outcome of the problem solution became a mathematical model; an optimization task, limiting and boundary conditions were formulated.
\end{abstract}

\section{Introduction}

Quality and reliable power supply of consumers always has been a high priority task for power grid companies. Moreover, power grid companies need to be energyefficient throughout their life cycle [1,2]. Distribution network constitutes the biggest part of a power electric grid. According to the data provided in [3], the share of the low- and middle-voltage power electric grids is about $85 \%$ of the whole power electric grid length. Furthermore, the $6(10) \mathrm{kV}$ power electric grid is a part of the power supply system that is connected directly to the consumers of electric energy; technological irregularities in its functioning lead to interruptions of the energy supplying to the consumers, which decreases the quality and reliability metrics of the company [4]. The main reason for the energy supply interruptions is the technological irregularities caused by short-circuits in the grid.

Appearance of short-circuits is a consequence of many factors - from the state of the installed equipment and climate conditions to some intentional illegal actions. An increase of quality and reliability of the energy supply can be achieved through following activities:

- activities against the appearance of technological irregularities;

- activities aimed to decrease the duration of technological irregularities and their consequences (including a decrease of consumers' shutdown duration).

This article is dedicated to the analysis of the second category of activities.

A decrease in the duration of technological irregularities (including a decrease of consumers' shutdown duration) in the 6(10) $\mathrm{kV}$ electric grid could be realised with reduction of the time needed for receiving the information about the appearance of irregularities and reduction of the time for the damage localization.
All these tasks can be successfully solved by means of Systems of the Automatic Power Supply Reinstatements (SAPSR). SAPSR constitutes from a combination of different components: commutating, electrical, tele-mechanical and tele-measurement equipment and software. However, a widespread implementation of SAPSR is limited due to the economic reasons - the equipment and the software are quite expensive.

One of the alternatives to the SAPSR are short-circuit indicator devices (SCID), which allow to considerably reduce the time for the damage localisation [5].

To evaluate quality and reliability of power supply companies, two main characteristics are commonly used: SAIDI - average duration of the energy supply interruption, SAIFI - average frequency of occurrence of energy supply interruptions [6].

These indicators are usually compared with planned values [7]. One of the ways to ensure matching the planned values of the indicator of the average duration of the power supply interruption is to reduce the time of the power supply interruption of consumers $t$, which is possible to implement, including through the use of SCID.

\section{Application of SCID in 6(10) kV distribution grid}

In practice, several obstacles may prevent implementation of SCID. The literature review allows to conclude, that the biggest problem is determination of the optimal position for SCID in the electric grid [8-10]. In addition, the principles and issues of the effectiveness of the installation are studied [11-13].

The article [10] is of a high interest, since it reviews both mathematical modelling and practical experiment of the optimal positioning of SCID. According to the work

* Corresponding author: diana.koeppen@lenze.com 
[14], it is important to provide not just some random level of the power supply reliability, and not the highest possible, but the optimal one from the point of view of operational cost-efficiency.

The main goal of the work was a development of a method for calculation of the optimal quantity of SCID, which would insure the optimal level of reliability by reasonable costs.

The goal includes several objectives:

- analysis of existing 6(10) kV electric grid schemes, proper for use of SCID;

- formulating a mathematical model, which would describe the interrelation of the characteristics of power supply reliability, main costs and the installed SCID quantity;

- determination of the optimization task limitations, taking into account the reliability metrics and main costs values;

analysis of mathematical modelling results and further investigation perspectives.

\section{Analysis of existing 6(10) kV electric grid schemes, proper for use of SCID}

SCID is an electric device that identifies a short-circuit current in the grid. Commonly $6(10) \mathrm{kV}$ distribution grid of overhead power lines has a scheme pictured in Figure 1.

The scheme in the Figure 1 has the following properties: branched topology, large number of branches, significant length of lines, single supply centre, great number of consumers, different length for main lines and branches. The branched topology and size of the scheme have a great influence on the duration of the energy supply interruption. Thus, the reliability indicators decrease and the risk to exceed the planned values arises.

The duration of the energy supply interruption can be assumed as a sum of several parameters:

$$
T=T_{\text {SEARCH }}+T_{\text {LOCALIZATION }}+T_{\text {RECOVERY }}
$$

where $T_{\text {SEARCH }}$ is the time needed to find the damage position; $T_{\text {LOCALIZATUON }}$ is the time needed for the damage containment; $T_{\text {RECOVERY }}$ is the time needed for recovery operations and reinstatement of the energy supply.

As practice shows, the value of $T_{\text {SEARCH }}$ is the highest, it depends on the network length, geographic and climatic conditions during the search for damage:

$$
T_{\text {SEARCH }}=\frac{l}{v_{\text {SEARCH }}}
$$

Where $l, \mathrm{~km}$ is the grid length (including main lines and branches); $v_{\text {SEARCH }}$, min is search rate.

To determine the interrelationship between the length of the grid, duration of the search for damage and the quantity of required SCID, the coefficient $\eta$ is used. It represents the number of SCID for one kilometre of the grid:

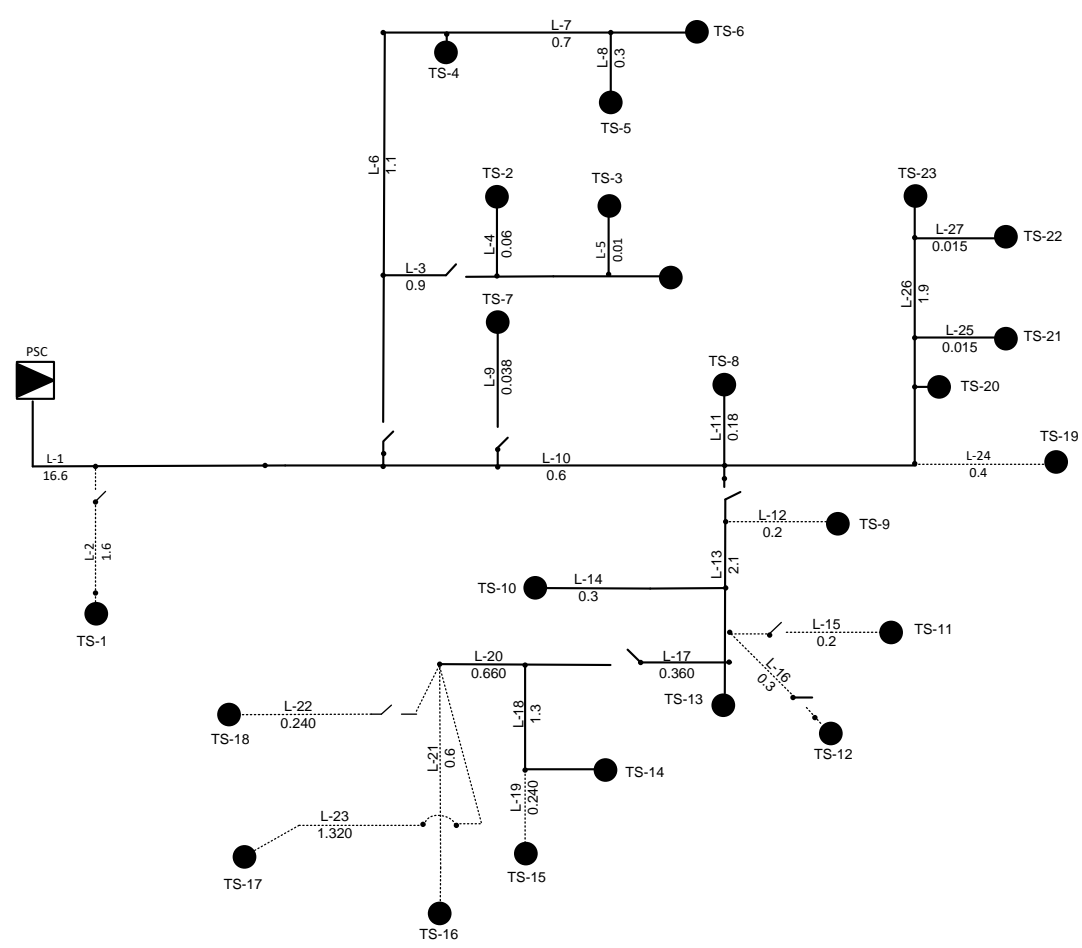

Fig. 1. Common view of the 6(10) $\mathrm{kV}$ distribution grid (PSC - power supply centre, L - overhead power line, TS - transformer substation). 


$$
\eta=\frac{l}{x}
$$

where $l$ is the grid length, as a sum of the main line length $l_{1}$ and the length of the branches $l_{2}$ :

$$
l=l_{1}+l_{2}
$$

$x$ is the number of SCID, required for the whole grid. This parameter is a sum of number of SCID installed on the main line $x_{1}$ and on the branches $x_{2}$ :

$$
x=x_{1}+x_{2}
$$

Therefore, the duration of the search for damage can be written as:

$$
T_{\text {SEARCH }}=\frac{x}{\eta \cdot v_{\text {SEARCH }}}
$$

With further modifications we obtain the following expression:

$$
\begin{aligned}
& T_{\text {SEARCH }}=\frac{\mathrm{x}}{\eta \cdot \mathrm{v}_{\text {SEARCH }}}=\frac{x_{1}+x_{2}}{\left(\frac{x_{1}}{l_{1}}+\frac{x_{2}}{l_{2}}\right) \cdot \mathrm{v}_{\text {SAERCH }}}= \\
& =\frac{l_{1} \cdot l_{2}}{\mathrm{v}_{\text {SEARCH }}} \cdot \frac{x_{1}+x_{2}}{x_{1} \cdot l_{2}+x_{2} \cdot l_{1}}=t \cdot \frac{x_{1}+x_{2}}{x_{1} \cdot l_{2}+x_{2} \cdot l_{1}}
\end{aligned}
$$

where $t$ is a constant that determines the lengths of main line and its branches, and the rate of the search for damage $\left(v_{\text {SEARCH }}\right)$. The value of $v_{\text {SEARCH }}$ is strongly dependant on the rate of the maintenance staff getting about the grid, geographic location of the grid and climatic conditions.

To get the values of SAIDI in the range of the planned values the following condition needs to be met:

$$
T_{\text {SEARCH }} \leq \Pi_{\text {SAIDI }}^{\text {PLAN }}
$$

Taking into account the condition from [10], mentioned in the introduction, it is required to determine an optimal quantity of SCID installations within the grid. According to the condition, the goal function can be formulated:

$$
z=a_{1} \cdot x_{1}+a_{2} \cdot x_{2}
$$

where $a_{1}$ is the price for installation of one SCID on the ramification line, thousand rubles; $a_{2}$ is the price for installation of one SCID on the main line, thousand rubles; $x_{1}$ is the number of SCID for installation on the main line; $x_{2}$ is the number of SCID for installation on the branches.
The optimization task can be formulated as search of the minimum for the goal function, i.e. minimal costs with a fulfilment of the required reliability condition:

$$
z \rightarrow \min
$$

Taking into account the limitations:

$$
t \cdot \frac{x_{1}}{x_{1} \cdot l_{2}+x_{2} \cdot l_{1}}+t \cdot \frac{x_{2}}{x_{1} \cdot l_{2}+x_{2} \cdot l_{1}} \leq \Pi_{S A I D I}^{P L A N}
$$

and the boundary conditions:

$$
\begin{aligned}
& x_{1}, x_{2} \geq 0 \\
& x_{1}, x_{2} \in Z^{+}
\end{aligned}
$$

In addition, the method considers an estimation of the SCID quantity for the grids with consistent equipment [15].

\section{Conclusions}

Several conclusions can be formulated, based on the investigation results:

- we have performed an analysis of existing power supply schemes for 6(10) kV distribution grid, which are compatible with SCID; specific characteristics of such grids have been identified;

- main parameters, having the greatest influence on the $6(10) \mathrm{kV}$ power supply reliability, have been analysed; as a main indicator, the duration of the power supply interruption has been stated; the value of duration of power supply interruption depends on the time for the search for damage in the grid;

- a mathematical model, describing the interconnection between the power supply reliability, the main costs and the quantity of SCID to install, has been formulated;

- the limitations of the optimisation task were determined: the value of the reliability indicators should not exceed planned SAIDI values.

\section{References}

[1] Golubzov N.V., Efremov L.G., Ismyatullin R.G., Energy efficiency of buildings from the aspect of their life cycle management Herald of Chuvash University 1, 247-55 (2013)

[2] Fedorov O.V., Assessment of influence parameters of electric equipment at a size of losses the electric power in intra factory networks of low voltage 2nd Int. Conference on Industrial Eng., App. and Manufacturing 7911463, 2 (2016)

[3] Annual report of JSC «Grid Company» for, the title from the screen, open access, http: // gridcomrt.ru / aktsioneram - i- investoram / obyazatelnoeraskrytie- informatsii-emitentami/godovye-otchety (2017)

[4] Musaev T.A., Povysheniye effektivnosti metodov upravleniya rezhimom raboty sistemy 
elektrosnabzheniya gorodskogo rayona diss. ... kand. tekh. nauk (2015)

[5] Kuznetsov B.V., Paramonov M.A., Vybor avtomatizirovannykh sistem razdeleniya vozdushnykh liniy elektroperedachi 6-10 $\mathrm{kV}$ na osnove mezhdunarodnykh pokazateley elektrosvyazi SAIDI, SAIFI Mat. dokladov XII Vserossiyskoy otkr. nauchnoprakticheskoy konf. «Dispetcherizatsiya i upravleniye v elektroenergetike» $400-4$ (2017)

[6] Gracheva E.I., Naumov O.V., Researches of indicators reliability and probabilistic characteristics of elements electric equipment of shop electric networks 2nd International Conference on Industrial Engineering, Applications and Manufacturing (ICIEAM), 1-4 (2016)

[7] Musaev T.A., Kamaliev R.N., Shageev S.R., Povysheniye effektivnosti formirovaniya tselevykh pokazateley nadezhnosti elektrosnabzheniya SAIFI, SAIDI dlya predpriyatiy setey obshchestvennogo pitaniya Energetik 8, 11 - 3 (2018)

[8] Almeida de M.C., Costa F.F., Xavier-deSouza S Santana F Optimal placement of faulted circuit indicators in power distribution systems Electric Power Systems Research 81, 699 - 706 (2011)

[9] Dashti R., Sadeh J., Fault indicator allocation in power distribution network for improving reliability and fault section estimation The int. conf. on advanced power system automation and protection 1406 - $11(2011)$

[10] Bandurin I.I., Smirnova A.A., Vybor metodov ustanovki indikatorov korotkogozamykaniya Metodicheskiye voprosy issledovaniya nadezhnosti bol'shikh sistem energetiki 267 - 75 (2016)

[11] Kopeykina T.V., Analiz povysheniya effektivnosti opredeleniya mestnykh povrezhdeniy na vozdushnykh liniyakh elektroperedachi Mezhdunarodnyy zhurnal prikladnykh i fundamental'nykh issledovaniy 12, 407 - 10 (2016)

[12] Belikov R.P., Fomin I.N., Ispol'zovaniye sredstv kontrolya i kommutatsii dlya udalennogo obnaruzheniya i obnaruzheniya primenitel'no $\mathrm{k}$ razvetvlennym elektricheskim setyam 6 (10) $\mathrm{kV}$ Agrotekhnika i energoobespecheniye 4(17), 77 - 86 (2017)

[13] Krasnykh A.A., Gavrilov G.G., Devet'yarova E.H., Opredeleniye optimal'nogo mesta razmeshcheniya na opore indikatora korotkogo zamykaniya pri vertikal'nom raspolozhenii provodnika Sbornik statey XVIII Vserossiyskoy nauchno-prakticheskoy konferentsii «Obshchestvo. Nauka. Innovatsii» 415 - 21 (2018)

[14] Markovich I.M., Optimizatsiya Rezhimov Energosistem (Moskva: Energoatomizdat) (1984)

[15] Bochkarev V.P., Fedorov O.V., Fufaev V.V., Effectiveness of controlling the structure of electrical equipment during technical reequipment Glass and Ceramics 44(9), 376 - 9 (1987) 